\title{
Global Peace and the Problem of Perfection as a Problem of Universal Connection
}

\author{
Alexander V. Malinin* \\ Siberian Federal University \\ 79 Svobodny, Krasnoyarsk, 660041, Russia
}

Received 04.02.2015, received in revised form 27.03.2015, accepted 06.04.2015

\begin{abstract}
The paper is devoted to perfection as an important social and philosophical issue. The author argues that perfection is determined by the universal connection of phenomena in nature and in society. It is proved that a systematic approach to the ways of improving human society helps to analyze society as perfection. Perfection, in the author's opinion, is manifested in the effort to comprehend the essence of the universal connection, which in the modern world stems from the ambiguity of the current globalization trends.

Problems of research of universal connection of phenomena is determined in many respects by the crisis of modern science, as it is arises out of a variety of methodological approaches, which eventually form fundamentally different pictures of reality.

In classical philosophy, there used to be a clear distinction between simple systems, that have been studied in physics or chemistry, and complex systems (scopes of biology and the humanities). Due to the original premise of the identity of thinking and being classical rationalism as a methodological principle initially expressed the relevance of humanistic knowledge, aimed at revealing, though abstract, semantic significance of the world. The integrity of modern European culture is preserved thanks to the predominant focus on science and belief that it is able to provide a person with a vital practical orientation in the world.

The established tradition of unquestioning reliance on Cartesian methodological framework has led to the gradual lost of the universal connection of phenomena; and the world is no longer perceived as coherent and unified, rather it appears as discrete and fragmented. Increasingly, the crisis condition of being comes forward. This condition fully reveals itself in the very problem of understanding the universal connections.

The universal connection of phenomena was present, in particular, in the second half of the 20th century, when there was a great increase of interest in myth as an attempt to explain the universal connections of phenomena by our ancestors. For most contemporary scholars it becomes apparent that thinking which does not regard the primordial time and being becomes defective and environmentally unfriendly, whereas the lack of artistic worldview, formed largely by cosmogonic myths, threatens to impoverish the culture.

The evaluation of the research is consistent with the relationship between a man and nature, but the process of obtaining these results implies dominating in nature studies understanding of the subjectobject relationship. The author emphasizes that therefore "a backbone" of research programs remains unaffected, although their targets anyway reflect the inherently social task, which is to contribute to the understanding and practical regulating the relations in the system "man-societynature".
\end{abstract}

(c) Siberian Federal University. All rights reserved

* Corresponding author E-mail address: Ale-malinin@mail.ru 
The article highlights that in order to understand the essence of the universal connection of phenomena it is important to consider the theory of the dual feedback, according to which the feedback in natural systems exists in two forms: informational and non-informational. It is believed that the noninformational type circulates in inanimate nature, and the informational type starts to function only at the level of organic matter. The organization of systems in the living world creates a completely different, new type of development mechanisms, unknown in inorganic nature, containing feedback mechanisms. This is the main feature that distinguishes the living from the nonliving creatures. However, some virus like creatures, traditionally assigned to the living world, still seemingly lack the ability to form a feedback loop.

The deepening ecological crisis, as well as new discoveries in physics, has brought the need to change the scientific paradigm, since classical science is unable to respond to new challenges. In this context, there are questions about what to do with nuclear waste, what measures to take against poverty, hunger, war threats, loss of biodiversity, pollution of the planet, etc.

According to the author, the universal connection, serving as perfection, involves the integration of all spheres of human activity and human knowledge in a single world process. This approach inevitably leads to dealing with problems that have become global in today's society, but have not been solved in the framework of the traditional scientific approaches.

Keywords: perfection, universal connection of phenomena, global world, crisis of existence, system, synergy, value diversity of the world.

Research area: philosophy.

Problems of research of universal connection of phenomena is determined in many respects by the crisis of modern science, as it is linked to a variety of methodological approaches, which eventually form fundamentally different perceptions of reality.

The need for special consideration of the philosophical problem of the world and culture unity is defined and formed by comprehension of numerous effects of integrity and interdependence of various processes and phenomena that are increasingly found, come to the fore not only in theory, but also in practical activity. These issues include ecology civilization and the biosphere, problems of general, universal unity of mega-, micro- and macrocosm. The tight combination of differentiation and integration of sciences is directly interconnected with tracking all the more profound, subtle correlations and correspondences in the very nature. The trend of the synthesis in some local cultures and civilizations is complemented by the intensification of transcultural dialogue. Awareness of national and ethnic specific features is not feasible without correlation with human values, invariants, sociocultural universal points.

The problem of the world unity runs through the whole history of philosophy, although it emerges in various forms, shapes, variations, conceptual approaches and conceptual modifications, projected onto the key, central, bearing meaning concepts, whether they are substance, being, material, fire, good, time, text, power, existence, will, idea, creation, representation, knowledge, structure or other. The traditional notions of universal connection of phenomena are mainly based on the idea of Isaac Newton, who created the concept of modern science in the period of absolute monarchy under the auspices of the existence of Almighty God, "the ultimate guarantor" of rationality. Western European concept of "natural law" simply cannot be observed in isolation from its legal and religious subcurrents: the ideal of knowledge was formulated in accordance with the ideas of Lord's omnipotence. For Him, there was no difference between the past and the future. Thus, from the point of view that the scientist is a human 
incarnation of the transcendental forces, time could really act only as an illusion.

Researchers, working on principles of universal connection often recite the position of Descartes on the need to "... stick to a certain order of thinking, starting with the simplest objects and the most easily recognizable and gradually going up to the knowledge of the most complex, assuming a certain procedure even where the objects of thought are not given in their natural connection" [Descartes]. The rooted tradition of unquestioning reliance on Cartesian methodological framework has led to the gradual lost of the universal connection of phenomena, whereas the world is no longer perceived as a coherent and unified, acquiring more and more discrete and fragmented character. The crisis conditions of being are becoming increasingly explicit; they show themselves fully in the problem of understanding of the universal connections

To create a unified picture of the world one had to find out the conditions of the transition from one representation to another and to connect different understandings of time: in the dynamics time is associated with the motion, in thermodynamics time is associated with the irreversibility, in biology and sociology time is associated with history. There is a kind of return to the mythological chaos, which was studied in the first explanations of the surrounding nature by ancient people. They perceive the chaos as possessing a certain harmony and integrity, but it only happens on a high technological level [Liseev].

The universal connection of phenomena is manifested, in particular, in the second half of the $20^{\text {th }}$ century, when there was a greatly increase of interest in myth as an attempt to explain the universal connection of phenomena of our ancestors. For most contemporary scholars it becomes apparent that thinking which does not regard the primordial time and being becomes defective and environmentally unfriendly, whereas the lack of artistic worldview, formed largely by cosmogonic myths, threatens to impoverish the culture.

Over time, the qualitative heterogeneity, hierarchical order of the cosmic spheres are replaced by the representation of the universe's homogeneity, the unity of the substance from which it is made. Being isolated from the nature and cosmic hierarchy, inclusion in which used to be inherent for people, a man was lost in the world of new science, the world that seemed disproportionate to the mental representation of the world. Modern science fixed a deep dualism between the natural and the human world, between the sphere of natural necessity and laws and a scope of goals and values. This dualism has been kept in the world view for a long time [Kedrov]. Such fragmentation of the world, being once united, more and more painfully hurts a person of our time, and requires a different approach to understanding and overcoming this problem. The ideal of the ever-increasing power of man over nature, heedless of its own integrity, faces serious contradictions, and in the near future follow this aspiration will result in a global crisis of civilization.

To manage global problems one needs to address the aggregate of all the practical solutions of topical problems of modern human civilization, however, the actual global (planetary) problems are born at the level of interaction of qualitatively different forms of matter motion in the process of interaction between the respective elements of the "nature-society" system. These elements include inanimate nature, biosphere (wildlife) and society. These are processes that have a crucial influence on the state and prospects of development of the main components of the complex "naturesociety" system and finally on the whole system, which essentially affect the nature of scientific truth, noted by E.M. Chudinov [Chudinov]. 
Inwildlife(animated nature)thecontradiction between the tendency to local stability and the desire to maximize the use of external energy and matter is one of the most important factors. Modern scholars point out that, in a sense, the idea of the food chain did away with the previous notion that the lower natural structures exist for the higher. The simplest life forms hold together all the life community and are of great importance to it. However, this did not stop the environmentalists, as noted by V. Boreiko, who continued on to take the shine out of mankind [Boreiko]. Today, unfortunately, the globalization processes make this process even more urgent.

A.N. Pavlenko mentions that we should not change the artificial environment, restoring it to the condition of the natural environment, but we had rather bring a person out of the natural state to a new, largely artificial condition [Pavlenko]. Externally, this attitude seems quite appropriate, demanded, as for the last decades the representatives of the modern "civilized world" have become so detached from their biological roots, while scientific and technological progress has begun to offer a sort of way out of any difficult situation. Nevertheless, it is clear that this approach is based on the theories of those scholars who continue to consider the system of relations between man and nature from the anthroposophic positions.

Supporters of the Western way of life are sure in their immense ambitions that only Europeanism has a real and substantial causal indissoluble bond, besides, it is available to everyone in the sources and able to be controlled. When we ask about the historical connection and semantic integrity, forming the basis of our existence, only in Europeanism, despite all its differences, we find the unity of meaning [Troeltsch]. The problems on the surface of the interaction between science and society, can only be resolved by understanding the real complexity of social processes [Kanaev]. If there is no this understanding, then the response of the system can be completely negative.

To study the essence of perfection, it is important to bear in mind that the typical features of today's world are, first, attempts to construct global models of the biosphere functioning, which exposed the most immediate complexity of the problem, involving the inclusion of a very wide range of natural sciences and the humanities in the work. Secondly, these attempts discovered a serious shortcoming of our knowledge for this purpose. Third, they have highlighted the problem of people, their nature, objectives and ways of development. And all these factors together move modern science to new, not posed previously problems [Kukushkina, Logunova].

Formation of ideas about holistic and systemic character in animated nature was historic, as the objectively holistic system objects of wildlife were not immediately perceived as such. Only with the advent of methodological orientation and regulatory principles of integrity and system character the representation data began to develop in the framework of these theoretical and methodological schemes [Shipunov].

Biosocial approach to man embraces an extensive variety of people's activities, but only as a holistic activities of real living person, really existing human population. Biosocial understanding of life, or rather, the subject activity of human life, creates the necessary conditions for the eventual connection of the entire system of biological knowledge to the problem of humankind.

To understand the essence of the universal connection of phenomena it is important to consider the theory of the dual feedback, according to which the feedback in natural systems is presented in two forms: informational and non-informational. The contradiction between the achievements and the negative effects 
of scientific and technological progress takes on a dramatic social form in the modern society: the “... a man from the mass has a sense of danger of totalitarianism, which is also often used to obtain the 'necessary' historical picture' [Iatsenko]

The approach, reflecting the co-evolutionary strategy, emphasizes and brings to light the diversity of independent and unmerged processes, coming close in polyphony, synergy of their interaction, openness, tolerance, incompleteness, unpredictability, coexistence and mutual conjugation of diverse evolutive processes, preserving their independence and, at the same time, combining in the unity of higher order [Liseev].

Coevolutionary cognitive model, acting as a universal methodological construct, reflects coevolutionary processes not only in the development of nature and culture, but also in the coevolution of ideas. S.N. Rodin writes that it is hard not to notice the similarities between the processes of occurrence, distribution and fixation of genetic variations in the biological coevolution and the processes, determining the fate of the scientific ideas, new knowledge and culture in general. In essence, we are talking about the birth of a new coevolutionary epistemology, which naturally inherits a purely evolutionary epistemology [Rodin]. Characteristically, in the process of mutual co-functioning, codevelopment or confrontation of ideas there are all the parameters of coevolutionary cognitive model. Here the researchers have stochastic processes, competition, selective selection and complementarity, and, often, the mutual negation at the initial stages, eventually leading to the synthesis. Most integrated synthetic disciplines in modern biology demonstrate vivid examples of such coevolution of ideas. Evolutionary biology integrates ideas, methods and approaches of different, often opposing directions and disciplines [Vorontsov].
The history of science shows that in the process of coevolution of ideas there is usually the accumulation and transformation of the ideas and theories, produced by the supporters of this or that conception and also the opponents to these ideas. L.I. Korochkin in several of his works analyzed the opposing concepts of preformation and epigenesis in biology [Korochkin].

A study of the system of universal connections as perfection involves consideration of the coevolution idea, which appears as a response to the challenge of modern technocratic civilization, the illusions of its domination over nature, its worldview, values and activity settings based on the idea of violence. The process of coevolution, as recorded in the bosom of biological knowledge, is more and more recognized as a universal process, gets indispensable for all levels of nature and society. The criterion for the knowledge allocation is not only conjugation of developmental processes, but also their orientation, taking into account the autonomy of interacting components, process and cooperative character, polyphony of interacting parties, with which the opposing processes and phenomena acquire stabilized equilibrium. All these points give grounds to say that coevolutionary strategy in the knowledge becomes a major paradigmatic setting of modern science. Yet, the concept of coevolution and the theory of the noosphere are not only mathematicians' domain. We need the most sweeping generalizations based on the joint efforts of scientists, mathematicians, economists, sociologists, psychologists, philosophers. Without such generalizations, as remarks N.N. Moiseev, "man cannot be understood in the entirety, in all the drama of the relationship with the rest of nature. Without such an understanding it is not even worth talking about any realistic specific strategy of interaction between nature and society" [Moiseev]. 
In modern conditions, many serious scientists come to the conclusion that the main source of environmental crisis is lax morals, so environmental crisis is first and foremost moral crisis, which requires the appropriate means. Not by chance, the participants of the seminar "Environmental Ethics in the $21^{\text {st }}$ Century" in their resolution state that environmental crisis is accompanied by a crisis of moral values. In this connection, more attention must be paid to the development of environmental ethics. Leading scientists believe that the future of the environmental movement also depends on the moral health of society [Boreiko].

The state of perfection in nature is a problem, which is to some extent included in the sphere of interests of representatives of various scientific disciplines. Naturally, the research methods of universal connection of phenomena are diverse in the natural sciences, since this problem is at the intersection of physics, chemistry, astronomy and other sciences.

The following comment seems quite justifiable in this regard: "In this case, it does not matter that the very understanding of the one-sidedness of Western history" (in terms of abstract rationalism of the Enlightenment philosophy, but which, as we know, did not reflect all Western philosophy of modern times) was largely rational and one-sided in its character). "What is important it is the fact of dissatisfaction of Khomyakov with rational philosophy of the New Age, in the possibility of overcoming which and the necessity of doing so he (like many other Russian religious thinkers) believed sincerely and passionately" [Boiko].

However, as Kuznetsov testifies, this is not a solution, but rather a new issue and the continuation of the same problem, as fundamental, the most profound unity escapes again, and the conditionality is optional. [Kuznetsov]
Social object as a single organism acquires special features in the concept of Hegel. Life of subjective spirit, presented in "Science of Logic", was considered by Hegel in almost the same terms with which Plato considers Socrates' notion about it; he also made it the object and therefore with the help of borrowing from the treasury of religion and poetry he lifted it above limitations and aimlessness. The initial act of human, selfreturning identity is skillfully woven into the life of "Everything" [Haym].

Biology has entered in recent years in an increasingly close cooperation with the sciences of man and society, reflecting the general trend towards convergence of the natural sciences and the sciences of man and society, which is, in particular, analyzed in V. Afanas'iev's book "The world of the living: consistency, evolution, management" [Afanas'iev]. This fact is of general scientific and philosophical significance. A possible example is the so-called "anthropic principle" in physics: Cosmos is arranged so as to provide the life of people. But the trend towards convergence of natural and socio-humanitarian knowledge is enormously important in today's life sciences.

Living beings are much closer to us, humans, than objects of physics, and therefore convergence between biology, social sciences and the humanities is more meaningful and more multifaceted than, say, convergence of physical and human sciences, although this convergence also plays an important role. One aspect of the social value of physics is that it gives a new perspective on the biological processes, and having biology as a mediator, physics appears on the social and political arena. This example is in the concept of the field forms of life by V.P. Kaznacheev [Kaznacheev], which is based on the physical representations of the wave-particle duality of matter applied to any living creature, including man. 
In this regard, it is difficult, according to some scientists, in particular Iu.P. Trusov, to agree with the proposal to create a "general environment", including chemical, physical, space systems, and present this environment as a variant of the general theory of systems [Trusov]. On the other hand, a single "semantic center" does not ensure homogeneity even within the ecology as a biological discipline, as objects are very complex and diverse. When the anthropobiological systems, human population, vast regions and even the planet Earth as a whole become such objects, it is more correct to speak not about ecology as a science, but about an ecological approach [Gerasimov].

Forming perfection in nature is linked to the fact that the ecological approach can not be identified to the system approach by virtue of the system approach to the environment, which is quite sharply polarized on systems analysis, with its inherent mathematisation procedures and a general system approach, used more in its philosophical, rather than in peculiar scientific value. In the first case, there is a socalled "theoretical system ecology", which has its own range of research tasks related to the formalization, to the using modern mathematical tools and general ideas of system analysis. As a rule, the empirical base of "system environment" is knowledge of relatively local natural situations. Because of this the existing claims to establish a general theory of environment sound not convincing enough, not to mention the epistemological limits of the formalization procedures. In the second case the system approach is discussed in the broader context of the relationship of science and the humanities, it emphasizes its connection with a historical approach and points out the ultimate, generally practical goal of the totality of environmental sciences, their axiological and humanistic content [Budyko].
Forming perfection in nature involves consideration of the fact that the means of environmental research, including a systematic methodology, are only the means and the aim is formulated in accordance with the social and economic needs of society, the demands of public life in general, the global challenge of preserving life on the Earth. In this regard, an interesting proposal of V.P. Kaznacheev is to consider the subject of science (not just the environmental science) in the aggregate of three components: an object, a method and a social order, formed by the society needs [Kaznacheev]. Ultimately, this approach gives a real chance not only for self-knowledge, but also for the survival of all humanity, as “... one of the main sources of Aristotle's thinking was the observation of embryonic development, a highly organized process in which there occurred interrelated, although seemingly independent events, as if obeying a common global plan like the developing fetus, so the whole Aristotelian nature is built on final causes. The purpose of any change, if it corresponds to the nature of things, is to implement in each of its bodies an ideal of rational entity. In this essence, which when applied to living, is at one and the same time, its final, formal and efficient cause, there is a key to understanding nature" [Prigozhin, Stengers].

Please note that the supporters of environmental ethics are often criticized, as that most of their offers cannot be realised. In this regard, we can cite the philosopher, who writes that "... it (ethics) is not a treatise about what it is ... not about how a man acts in real life, but it is about how he should behave to justify the human quality ... Forgetting about the main purpose of ethics as a science was almost the only source of many errors in the understanding of ethical problems" [Giliarov]. In other words, there is environmental ethics of necessity, but also there is environmental ethics of the ideal. 
In our relations with nature we must strive to the ideal ethics, but also we should always follow the ethic of the necessity. As A.S. Panarin reasonably pointed out: “... a technical catastrophe of already strategically planned world conflict will certainly be accompanied by a humanitarian disaster affecting the very foundations of this way or another existing human understanding and mutual recognition. These very followers of the great new teaching, who only yesterday so persistently harped on pluralism and consensus, will be everywhere to seek out cultural and psychological traits that are not compatible with the practice of the liberal consensus, putting those having these features beyond the "civilized society" [Panarin].

New environmental ethic based on equality of human and nature is not needed as saving nature is possible by continuing putting human interests before everything else. The specific effects of bio-power are monitored in areas of interdisciplinary conflict between biomedical and moral discourse, grouped around the issues of "existence", "essence" and "number" of people [Tishchenko].

The problem of compatibility of nature and society, as it was already emphasized, arises out of the destructive human activities. Nonetheless, despite the fact that in some cases there is such a tendency actually, it does not mean that the destructiveness as such is simply passed on from generation to generation. For example, according to A. Maslow, destructive forces in people are the result of the frustration of basic needs [Lysak], which clearly characterizes the very universal project of science. It is this common anthropocentric worldview which is today a universally recognized foundation of all human activities, and is to be laid in the foundation of already known future scenarios [Kozlov].

Forming perfection in nature is seen differently by different scientists. In particular,
V.P. Kaznacheev defines multiple destinations as follows: "Human ecology is a complex interdisciplinary scientific direction, exploring the patterns of interaction of people populations with the environment, the problems of population development in the course of this interaction, the problems of targeted management of the population conservation and development, improving Homo Sapiens as a species. One can say that the laws of the noosphere development, the state of the structure, functions of human population on the criteria of their biosocial health, the processes of interaction with the environment, life support systems are the subject of human ecology" [Kaznacheev].

Pierre Teilhard de Chardin poses the question about the meeting and mutual enrichment of the two noospheres, but he only extends to the psyche sphere the values' scale, the validity of which is no longer disputed. The consciousness creates itself in the long run by the synthesis of planetary units [Chardin]. Awareness of the universality of coevolutionary relationship started as if from "upper floors" of relations between society and nature, between man and biosphere. Throughout the history of human civilization there have been two mutually exclusive strategies of relations between man and nature: the target of the conquest of nature and the theme of humility in front of it. Catastrophic growth of ecological trouble in the world today promote awareness of restrictions and deadlock of both these strategies. People have much clearer understanding that it is impossible to rely only on anthropogenic or vital, natural factors. Only keeping their organic interaction, interconnection, interdependence, as well as a clear understanding of the laws of their conjugation, coevolution may become a key to the successful development of a new strategy for relations between man, society and nature.

Forming perfection in nature is closely linked with new trends in philosophy, which is 
increasingly starting to evolve around itself. This has always been distinguished in reflexivity; it simply proved no longer possible to continue to understand the development of philosophy as linear and continuous, or to carry out simple transfer of its own concept to the historical and philosophical basis, in the spirit of, for example, Aristotle and Hegel. At the same time there began to appear more and more clearly the crisis tendencies, causing a critical rethinking of the way philosophy has already worked up.

Understanding society in the sense of strict reductionist theories, offering to reduce all social processes to straightforward laws of economic, biological, etc. determinism, though allowing building a universal explanatory and simplifying scheme, rules out the possibility for adequate display of the manifold cultural and civilizational phenomena. What is more, plural concepts, though allowing the simultaneous operation of several lines determining social phenomena, are not viably successful, as they lead eventually to the crumbling fragmentation, which does not cover completely multidimensional and multivariate social body in its entirety. Therefore, the problem is apparently to overcome a particularly strong opposition between monism and plurality [Kuznetsov].

In any case, there are unavoidably focused, inescapable unity, coherence, wholeness of all reality, reality, all varieties of the universe, macrocosm; all these notions are covered and fixed in one way or another in the conceptualcategorical coordinates. Both classic study of the phenomenon, nonclassical simulation of the variable and post-nonclassical deconstruction are forced nevertheless to revolve around the problems of the world and keep coming back to the question of its unity. It is true in this respect to remember V.V. Bibikhin, who said: "Whatever and whenever a concept of man and the world appear, their understanding does not occur other than out of the man's captivity by the world, out of the man's comprehension of the world, so these captivity and comprehension each time for each person are what they are, they will always stay this early origin, something beyond which human knowledge will never go [Bibikhin].

An analysis of the balance of social systems is important from the perspective of the institutionalization of normative culture, i.e. preservation of the essential characteristics of the system. The violation or the collapse of the balance of the social system leads to a violation in not only the structural integrity of the system, but also to the appearance of pathological defects, to the collapse of the very system.

The essence of scientific knowledge with a modern twist is an integrating generalizing description of the diverse phenomena of reality on the basis of universally valid cognitive procedures. Thus, the hope for mere logical scientific knowledge, the possibility of infinite knowledge and solution of all problems, as pointed out by other researchers [Kivenko], is a harmful and dangerous delusion. That is why it is right to speak of social life as a phenomenon, whose driving forces are better for the environment, the biosphere factors, such as studied by L.N. Gumilev rhythms of ethnogenesis, including the expansion, depression and decline phases. Indeed, an understanding of the fact that our ancestors and contemporaries had to spend a lot more energy on the development of the land is often overlooked in studies, unfortunately. In this respect, the theory of L.N. Gumilev has natural science foundation, according to which, as the L.M. Martseva observes: "... the state of changes in biochemical energy of living matter are determined by climatic and natural changes depending on the people either little or not at all" [Martseva]. By analyzing the interaction of biological and social factors as a basis for the formation of an alternative project of science, 
Gumilev noted that "banal Eurocentrism is sufficient for Philistine perception and does not fit for scientific understanding of the variety of observed phenomena" [Gumilev].

Along with the traditional attitude towards nature in terms of domination over it, in today's world there is a tendency to look for an alternative concept, in which the main part is the process when harmonious and morally responsible society is getting used to the nature.

This approach stems from the fact that the current conditions in the physics of relativity, quantum mechanics, linguistics, ethnology, psychology, sociology can no longer ignore the role of the observer in the process of acquiring knowledge. The formulation of the knowledge about the object is dependent on the results of the study of phenomenon of consciousness. In science, there is inevitably intensified desire for a deeper comprehension of nature, its internal relationships, in which the object of study and the knowing subject are not separated with an insurmountable barrier [Losskii].

Berdyaev even in 30 s of the last century believed that "a holistic anthropology has not been created: people have seen this or that aspect of a person, but not an integral person in complexity and unity" [Kiselev]. An important point here is that the Russian Christian consciousness often sought something outside the historic church life. For example, L. Tolstoy in fact argued about the need for a new church; and at the beginning of the last century, the representatives of the so-called "new religious consciousness" were trying to reconcile the traditional orthodoxy and religious seekers among the intellectuals, including philosophers, who reconsidered the social sphere.

The reform of our society in the context of globalization requires to proceed from the fact that the idea of unity is at the forefront of the Russian scientific and philosophical belief system, thus allowing us to consider the world and its underlying laws as the indivisible whole. It is the Russian scientific thought in its cosmic manifestation which combines scientific, philosophical and social aspects of human knowledge organically, therefore creating the basis of a positive trend in the scientific development of mankind.

In the global world, the problem of perfection acts as a universal connection of phenomena, and the concept of forming perfection is closely linked to the type of society, as an idea of unity, purpose and sense of perfection is formed on the basis of historical values, traditions, mentality, etc.

Thus, theactivityofharmoniouscompatibility of nature and society, given the universal connection of phenomena is only possible, when people get rid of the anthropocentric idea about nature exploration. For an optimal solution to the problem of compatibility between activity and society there is a need to bring scientific and philosophical knowledge to the dialectic ideal balance between rational and unrational.

\section{References}

1. Afanas'iev, V.G. Mir zhivogo: sistemnost', evoliutsiia, upravlenie [The world of the living: system character, evolution and management]. M.: Politizdat, 1980.

2. Bibikhin, V.V. Mir. Proiasnenie situatsii [The World. Clarification of the situation]. St. Petersburg, 2007. Pp. 428-429.

3. Boiko, P.E. Ideia Rossii v russkoi filosofii istorii [The idea of Russia in the Russian philosophy of history]. M., Publishing House "Socio-political thought" (Sotsial'no-politicheskaia MYSL'), 2006. P. 69. 
4. Boreiko, V.E. Proryv v ekologicheskuiu etiku [A breakthrough in the environmental ethics]. Second edition, revised. Kiev Ecological and Cultural Centre, 2001.

5. Boreyko, V.E. (1977). Roderik Nash i moral'nye prava prirody [Roderick Nash and the moral rights of nature]. Seriia: Istoriia okhrany prirody. Kievskii ekolog-kul'turnyi tsentr PRAVA PRIRODY (Series: History of nature protection Ecological and Cultural Center of the Rights of Nature. History of Environmental Ethics). Kiev Ecological and Cultural Centre, 2001.

6. Budyko, M.I. Global'naia ekologiia [Global Ecology]. M.

7. Chudinov, E.M. Priroda nauchnoi istiny [The nature of scientific truth]. M., 1977.

8. de Chardin, P.T. Fenomen cheloveka [The Phenomenon of Man]. M., Progress, 1965.

9. Descartes, R. Rassuzhdeniia o metode dlia khoroshego napravleniia razuma i otyskaniia istiny v naukakh [Discourse on the Method of Rightly Conducting One's Reason and of Seeking Truth in the Sciences]. Mir fiolosofii. Chast' 1 (The world of Philosophy. Part 1.). M., Politizdat, 1991. P. 498.

10. Gerasimov, I.P. (1978). Metodologicheskie problem ekologizatsii sovremennoi nauki [Methodological problems in the greening of modern science]. Voprosy filosofii (Issues of Philosophy), 11 .

11. Gilyarov, A. (1976). Chelovek i zhivotnoe [Human and animal: the ethics of relationships]. Nauka i zhizn' (Science and Life), 12.

12. Gumilev, L.N. Etnogenez i biosfera Zemli [Ethnogenesis and biosphere of the Earth]. M., 1989. P. 65.

13. Haym, R. Gegel' i ego vremia [Hegel and His Times]. St. Petersburg, Nauka, 2006. Pp. $70-$ 71.

14. Iatsenko, M.P. (2010). Globalizatsiia kak forma istoricheskogo protsessa i aksiologiia istorii [Globalization as a form of historical process and axiology in history]. Nauchnye problemy gumanitarnykh issledovanii (Scientific Problems of Humanitarian Studies), 9. Piatigorsk. P. 238.

15. Iudin, B.G. (1984). Sotsiokul'turnye kharakteristiki teoreticheskogo znaniia v biologii [Social and cultural characteristics of theoretical knowledge in biology]. Puti integratsii biologicheskogo $i$ sotsiogumanitarnogo znaniia (Ways to integrate the biological and socio-humanitarian knowledge). $\mathrm{M}$.

16. Kanaev, N.M. (2003). Globalizatsiia kak ugroza kul'turnomu raznoobraziiu i sotsial'noustoichivomu razvitiu [Globalization as a threat to cultural diversity and social and sustainable development]. Kul'tura informatsionnogo obshchestva: sbornik nauchnnykh trudov (Culture of the information society: Collection of scientific works). Krasnoyarsk, KSTU, Publishing and printing centre.

17. Kaznacheev, V.P. Ocherki teorii i praktiki ekologii cheloveka [Essays on the theory and practice of human ecology]. M., 1983. Pp. 79-87.

18. Kedrov, B.M. The subject and the relationship between the natural sciences [Predmet $\mathrm{i}$ vzaimosviaz' estestvennykh nauk]. M., Nauka, 1967.

19. Kiselev, G.S. (2006). Smysly i tsennosti novogo veka [Meanings and values of the new century]. Voprosy filosofii (Issues of Philosophy), 4. P. 8.

20. Kivenko, N.V. The principles of knowing the living thing [Printsipy poznaniia zhivogo]. Kiev: Vishcha Shkola, 1991. 
21. Korochkin, L.I. Preemstevennost' idei i formirovanie paradigmy v biologii i genetike razvitiia [The continuity of ideas and the formation of the biology and developmental genetics paradigm]. Logika, metodologiia i fiolosofiia nauki, Materialy VII Mezhdunarodnomu kongressu po logike, metodologii i filosofii nauki (Logic, Methodology and Philosophy of Science. Materials for the VII International Congress on Logic, Methodology and Philosophy of Science). M., 1987.

22. Kozlov, B.I. Tekhnika kak okruzhaiushchaia sreda [Technology as the environment]. Tekhnika, obshchestvo i okruzhaiushchaia sreda: materialy mezhdunarodnoi nauchnoi konferntsii (Technology, society and environment: Proceedings of the International Scientific Conference (18-19 June 1998)). M., 1998.

23. Kukushkina, E.I., Logunova, L.B. Mirovozzrenie, poznanie, praktika [Worldview, knowledge practice]. M., Politizdat, 1989.

24. Kuznetsov, V.Iu. Mir edinstva [The world of unity]. M., Akademicheskii Project; Alma Mater, 2010. Pp. 17-22.

25. Liseev, I.K. Tekhnika i priroda: garmoniia, protivostoianie ili ..? [Technology and nature: harmony, confrontation, or ..?]. Tekhnika, obshchestvo $i$ okruzhaiushchaia sreda: materialy mezhdunarodnoi nauchnoi konferntsii (Technology, society and environment: Proceedings of the International Scientific Conference (18-19 June 1998)). M., 1998.

26. Losev, A.F. Dialektika mifa [Dialectics of Myth]. Filosofiia. Mifologiia. Kul'tura (Philosophy. Mythology. Culture). M., Politizdat, 1991.

27. Losskii, N.O. Mir kak organicheskoe tseloe. Izbrannoe [The world as an organic whole. Selected works]. M., Pravda, 1991.

28. Lysak, I.V. Chelovek - razrushitel': destruktivnaia deiatel'nost' cheloveka kak sotsiokul'turnyi fenomen [Man - the destroyer: destructive activities of man as a social and cultural phenomenon. Taganrog, Publishing House of Taganrog State Radiotechnological University, 1999.

29. Martseva, L.M. (2002). Osobennosti khoziaistvennogo osvoeniia prostranstvennovremennykh granits rossiiskoi tsivilizatsii (Opyt sopostavleniia) [Features of economic development of spatial and temporal boundaries of the Russian civilization (Experience of comparison)]. Teoriia $i$ istoriia (Theory and History), 1. P. 17.

30. Moiseev, N.N. Chelovek. Sreda. Obshchestvo [Man. Environment. Society]. M., 1982. P. 34.

31. Panarin, A.S. Strategicheskaia nestabil'nost' XXI veka [Strategic instability of the XXI century]. M., 2002. No.12.

32. Parsons, G. Chelovek v sovremennom mire [A man in the modern world]. M., Progress, 1985. Pp. 249-250.

33. Pavlenko, A.N. (2002). "Ekologicheskii krizis" kak psevdoproblema ["The ecological crisis" as a pseudoproblem]. Voprosy fiolosofii (Issues of Philosophy), 7.

34. Prigozhin, I., Stengers, I. Poriadok iz khaosa [Order out of chaos]. M., 1986. Pp. 83-84.

35. Rodin, S.N. Ideia koevoliutsii [The idea of coevolution]. Novosibirsk, 1991.

36. Shipunov, F.Ia. Organizovannost' biosfery [Organized nature of the biosphere]. M., Nauka, 1980.

37. Tishchenko, P.D. Bio-vlast' $v$ epokhu biotekhnologii [Bio-power in the era of biotechnology]. M., 2001. 
38. Troeltsch, E. Istorizm i ego problem [Historicism and its problems]. M., Iurist, 1994. Pp. 605606.

39. Trusov, Iu.P. O predmete i osnovnykh ideiakh ekologii [On the subject and the main ideas of ecology]. Filosofskie problem global'noi ekologii (Philosophical problems of the global ecology). M., 1983.

40. Vorontsov, N.N. Evoliutsionnaia biologiia-novaia sinteticheskaia otrasl' biologii [Evolutionary biology - a new synthetic industry of biology]. Dialektika v naukakh o prirode i cheloveke. Evoliutsiia materii i ee strukturnye urovni (Dialectics in the sciences of nature and man. The evolution of matter and its structural levels). M., 1983. Pp. 295-302.

\title{
Глобальный мир и проблема совершенства как проблема всеобщей связи
}

\author{
А.В. Малинин \\ Сибирский федеральнылй университет \\ Россия, 660041, Красноярск, пр. Свободньй, 79
}

Статья посвящена исследованию совершенства как важной сочиально-философской проблемы. Автор доказывает, что она детерминирована всеобщей связью явлений как в природе, так и в обществе. В статье доказывается, что системный подход к совершенствованию человеческого общества помогает анализировать социум как совершенство. Совершенство, по мнению автора, проявляется в стремлении постижения сущности всеобщей связи, что в современном мире связано с неоднозначностью протекания глобализационных тенденций.

Проблематика исследования всеобщей связи явлений во многом детерминирована кризисом современной науки, поскольку это связано с различными методологическими подходами, формирующими в конечном счете принципиально разные картины окружающей действительности.

В классической философии существовало четкое различие между простыми системами, которые изучались физикой или химией, и сложными системами, изучаемыми биологией и гуманитарными науками. Классический рачионализм как методологический принцип в силу исходной посылки о тождестве мышления и бытия выражал изначально позицию гуманистического знания, ориентированного, хотя и в абстрактной форме, на раскрытие смысловой значимости мира. Целостность новоевропейской культуры сохраняет преобладающую ориентачию на науку и уверенность в том, что она способна дать человеку жизненно-практическую ориентацию в мире.

Сложившаяся традиция о безоглядной опоре на декартовскую методологическую основу привела к тому, что постепенно теряется всеобщая связь явлений и мир перестает восприниматься как иелостный $u$ единый, все больше приобретая дискретный $и$ фрагментарный характер. Все в большей степени дает о себе знать кризисность бытия, которая в полной мере проявляет себя именно в проблеме понимания сущности всеобщих связей

Всеобщая связь явлений проявляется, в частности, в том, что во второй половине ХХ века значительно вырос интерес кмифу как попытке объяснения всеобщей связи явлений натими предками. Для большинства современных ученых становится очевидным, что мышление, которое не чувствует первоосновы бытия и времени, становится неполноценным и 
экологически опасным, а отсутствие художественной картины мира, в формировании которой большую роль сыграли космогонические мифы, угрожает упадком культуры.

Оиенка результатов исследования сообразуется с отношением «человек - природа», но сам процесс получения этих результатов ориентирован на господствующее в естествознании понимание субъект-объектного отношения. Автор подчеркивает, что «костяк» научноисследовательских программ остается незатронутым, хотя в их целевых установках так или иначе отражена соииальная по своей сути задача - способствовать пониманию и практической регуляции отношений в системе «человек - общество - природа».

В статье особо подчеркивается, что для понимания сущности всеобщей связи явлений важно учитывать теорию двойственной обратной связи, согласно которой обратная связь в природных системах представлена в двух формах: информационной и неинформационной. Считается, что неинформационный тип распространен в неживой природе, $а$ информационный появляется начиная с органического уровня материи. Организация систем в живом мире порождает совершенно иной, новый, тип механизмов развития, неизвестный в неживой природе, содержащий механизмы обратной связи. Это и есть главная особенность, которая отличает живое от неживого. Однако некоторые вирусоподобные существа, традиционно относимые к живому миру, по-видимому, все-таки лишены способности формировать петли обратной связи.

Углубление экологического кризиса, а также новые открытия в области физики актуализировали вопрос о необходимости смены научной парадигмы, поскольку классическая наука не в состоянии ответить на новые вызовы. Именно в этом контексте возникают вопросы о том, что делать с ядерными отходами, что предпринять против нищеты и голода, угрозы развязывания войн, сокращения биологического разнообразия, загрязнения планеты и т.д.

По мнению автора, всеобщая связь, выступающая как совершенство, предполагает интеграцию всех сфер человеческой деятельности и человеческого знания в едином мировом прочессе. Такой подход с неизбежностью подводит к проблемам, ставшими глобальными в современном обществе, но не решаемыми в рамках традицонных научных подходов.

Ключевые слова: совершенство, всеобщая связь явлений, глобальный мир, кризисность бытия, система, синергетика, ценностное многообразие мира.

Научная спеииальность: 09.00.00 - философские науки. 